\title{
The Analysis of Intangible Costs of Trade Companies in Serbia
}

\author{
Radojko Lukić \\ Full Professor, Faculty of Economics,University of Belgrade, Belgrade, Serbia \\ E-mail: rlukic@ekof.bg.ac.rs \\ Veselin Perović \\ Full Professor, Faculty of Technical Sciences, University of Novi Sad, Novi Sad, Serbia, \\ E-mail: vesa@uns.ac.rs
}

Received (28.12.2018.); Revised (11.01.2019.); Accepted (20.02.2019.)

\begin{abstract}
There has been increased attention directed lately, both in theory and in practice, to investigating the impact of intangible assets on company performance. In this context, the importance of intangible costs, i.e. amortization of intangible assets, is also considered. Bearing this in mind, this paper examines the impact of intangible costs on the performance of trade companies in Serbia. The conclusion is that they are an increasingly important factor in the performance of trade companies in Serbia. In support of this, the fact is that there is a high correlation between intangible costs and sales revenues.
\end{abstract}

Key words: innovations, customers, brand, technology, knowledge, Jel classification: L810, M420, Q320

\section{INTRODUCTION}

Due to the considerable importance more attention is paid lately to the problems of analyzing intangible assets, that is, the intangible costs and their impact on the performance of all enterprises, including trading. This is quite understandable given the fact that the share of intangible assets in their total assets is increasing. For illustration purposes, in 2015, the relationship between intangible and tangible investments in UK trade was 1.37: 1 [16].

The subject of research in this paper is the determinants of the dynamics of intangible costs and their impact on the performance of trading enterprises, with a special emphasis on Serbia. The aim of the research is to address the issues more comprehensively as the basis for the most efficient management of the intangible costs of trading companies in Serbia in order to achieve the target total (profit and other) performance, with maximum satisfaction of customers' needs.

In developing theoretical and methodological work during researching the issue of intangible assets, we used the most relevant contemporary literature in the field. In recent years, due to the great importance, a lot material is written about the role, importance and influence of intangible assets, i.e. intangible costs on the efficiency and competitiveness of enterprises [2] [10] [7] [22] [20] [3] [1] [5] [8] [16] [19].

Regarding the literature in Serbia, and as far as we know, there is almost no complete work dedicated to the analysis of intangible assets, i.e. intangible costs, in particular for trade companies in Serbia [11] [12] [13]
[14] [17] [18] [21]. This gap is partly filled with this work, in what we find its scientific and professional contribution.

Given the complexity and underdevelopment of the treated problems in this paper (especially in the literature in Serbia), different research hypotheses can be defined. The primary research hypothesis in this paper is that the impact of intangible assets on the economic and financial performance of trading enterprisesis in creasing. This is confirmed by the results of the research in this paper, on the example of trade companies in Serbia.

Following the character of the treated problem, the primary methodology of the research is a comparative analysis. To a certain extent, statistical analysis was used so as to make more credible confirmation of the obtained results of empirical research, especially in the case of trade companies in Serbia.

The original empirical data from different comparable sources was collected for the purpose of investigating the treated problems in this paper.

Certain empirical data are collected from published articles in relevant journals. For the analyzed global retail chains, the necessary empirical data are collected from their published annual financial statements for the observed years. Regarding trade companies in Serbia, empirical data are obtained from the Business Registers Agency.

The used empirical data are comparable so there are no limitations in this paper in terms of the validity of the results of the research. This fully applies to the applied methodology of the research. 


\section{DEFINITION AND SPECIFICITY OF INTANGIBLE ASSETS IN TRADE ENTERPRISES}

In the general sense, intangible assets are specific regarding their character and the structure in relation to tangible assets, and there are various forms of intangible assets. Typical forms of intangible assets are: computerized information (software and database), innovative assets (research and development - R \& D, research of mineral resources, financial innovation, design, original works of art) and economic competence (branding - propaganda, market research, organizational capital, acquired organizational capital, training).

Table 1 shows the detailed categorization of intangible assets applicable to almost all companies, including trade.

Table 1. Measurement for intangible assets framework

\begin{tabular}{|c|c|c|c|}
\hline Broader category & Type of intangible assets & Description (CHS) & $\begin{array}{c}\text { Capitalisation in } \\
\text { national accounts? }\end{array}$ \\
\hline $\begin{array}{l}\text { Computerised } \\
\text { information }\end{array}$ & Software and database & $\begin{array}{l}\text { Includes built-in } \\
\text { knowledge, software } \\
\text { and databases. }\end{array}$ & Yes \\
\hline \multirow{5}{*}{ Innovative property } & $\begin{array}{l}\text { Research and } \\
\text { development }\end{array}$ & & Yes \\
\hline & Mineral exploitation & & Yes \\
\hline & Artistic originals & $\begin{array}{l}\text { Includes knowledge } \\
\text { acquired through } \\
\text { scientific research, } \\
\text { product development } \\
\text { and non-scientific } \\
\text { inventive and creative } \\
\text { activities. }\end{array}$ & Yes \\
\hline & Design & & No \\
\hline & $\begin{array}{l}\text { Financial innovative } \\
\text { products }\end{array}$ & & No \\
\hline \multirow{3}{*}{$\begin{array}{l}\text { Economic } \\
\text { competencies }\end{array}$} & Branding & & No \\
\hline & Organisational capital & $\begin{array}{l}\text { Includes built-in } \\
\text { knowledge in firm- } \\
\text { specific human and } \\
\text { structural resources, as } \\
\text { well as the brand's } \\
\text { name. }\end{array}$ & No \\
\hline & Firm-specific training & & No \\
\hline
\end{tabular}

Note: Corrado-Hulten-Sichel (C-H-S) framework Source: Martin, (2018)

Significant forms of intangible assets are: information innovation, new product development, branding, innovation in human capital management, and organizational changes. Computer information, research and development $(R \& D)$, mineral resources research and original work of art are generally capitalized [5]. For illustration purposes, in 2015, the UK has a significant percentage $(23.7 \%)$ of capitalized intangible assets in trade [6]. The size of the firm affects the amount of investments in intangible assets. In the European Union countries, the correlation between investments in intangible assets and the size of a firm in trade is: the intangible share 0.29 and the ratio of intangible/tangible assets 0.45 [1].

It is specific, and in particular its houldbe noted that the structure of intangible assets in retail companies has changed significantly in recent years. Typical new forms of intangible assets in retail include the development of a private brand, franchising, employee training, radio frequency identification - RFID, internet trade, innovations in theft management, financial innovation products (especially in the domain of payment of purchased products) and others.

In recent years, the importance of a private brand has become increasingly important. As to illustrate, Table 2 shows the private trademark trend by country. In 2016, 
at the global level, a private brand participated with $16.7 \%$ and in Europe with $31.4 \%$ (according to:] http://www.nielsen.com/sa/en/insights/news/2018/privat e-label- brands-are-hungry-for-more-of-the-global-foodpie.print.html) (July 12, 2018). The share of private brands (volume) in some countries is over $50 \%$ (Switzerland, Spain). A private brand is particularly popular in Germany (with a $45 \%$ share) (according to: https://www.supermarket.co.za/news-

article.asp? ID=7386\&CatTags=9-Supplier\%20news)

(July 12, 2018).
The return on investment in private brand, measured by the annual growth rate (CAGR - Computed Annual Growth Rate) for the four-year period is $2.0 \%$, and for branded products for the same time period is $1.2 \%$ (according to https://www.foodnavigatorusa.com/Article/2018/04/05/Nielsen-on-private-labelWe-ve-seen-a-complete-reversal-in-growth-trajectorycompared-to-manufacturer-branded-items) (July 12, 2018).

Table 2. Private trademark by country

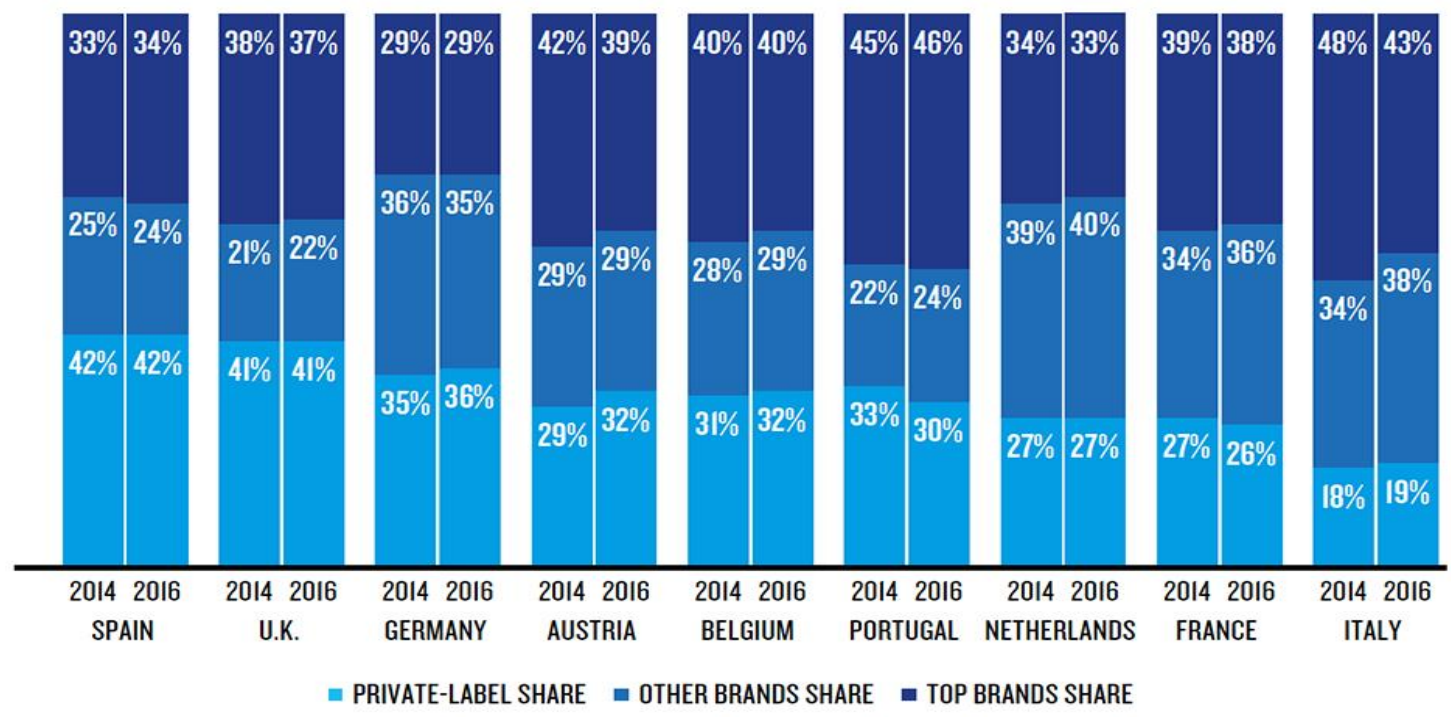

Source: The rise and rise of private label, Nielsen, http://www.nielsen.com/uk/en/insights/reports/2018/the-rise-andrise-again-of-private-label.html (July 12, 2018)

It is widely known that the brand belongs to very important factors both in terms of value and performance of a retail company. It is considered that "business success is better achieved with a good brand" than a "branched retail network". Table 3 illustrates the value of the of top 10 retailers' brands.

Table 3. The value of the brand of top 10 retailers

\begin{tabular}{|c|c|c|c|c|c|c|c|c|}
\hline & & & \multicolumn{2}{|l|}{ Rank } & \multicolumn{2}{|c|}{$\begin{array}{l}\text { Brand Value } \\
\text { (USD \$ Millions) }\end{array}$} & \multicolumn{2}{|c|}{ Brand rating } \\
\hline 2017 & 2016 & Logo & Name & Country & 2017 & 2016 & 2017 & 2016 \\
\hline 1 & 1 & amazon & Amazon & 瞟 & 106,396 & 69,642 & AAA- & AA+ \\
\hline 2 & 2 & Walmart $:=$ & Walmart & 閂 & 62,211 & 53,657 & $\mathrm{AA}+$ & AA \\
\hline 3 & 5 & $e^{2}=0$ & Alibaba & 2 & 34,859 & 17,968 & $\mathrm{AA}+$ & AA+ \\
\hline 4 & 3 & 湶 & The Home Depot & 鄙 & 30,216 & 28,798 & AAA- & AAA- \\
\hline
\end{tabular}




\begin{tabular}{|c|c|c|c|c|c|c|c|c|}
\hline 5 & 6 & IKEA & IKEA & 局 & 24,119 & 17,009 & AA & AA \\
\hline 6 & 4 & rcvs shamaracr & CVS & 鄙 & 23,286 & 22,891 & $\mathrm{AA}+$ & AA+ \\
\hline 6 & 6 & rovs carematik & CVS Caremark & 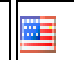 & 23,286 & 22,891 & $\mathrm{AA}+$ & $\mathrm{AA}+$ \\
\hline 7 & | 7 & ○ & Target & 囬 & 17,016 & 15,331 & $\mathrm{AA}+$ & AA \\
\hline 8 & 8 & Teralgreens & Walgreens & 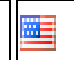 & 15,969 & 14,315 & $\mathrm{AA}+$ & AA \\
\hline 9 & $\mid 9$ & 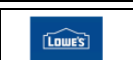 & Lowe's & 鵖 & 13,938 & 12,717 & AAA- & AA \\
\hline
\end{tabular}

Source: Retail 50 2017: The most valuable retail brands of 2017, http://brandirectory.com/league_tables/table/retail-502017(July 12, 2018)

As is well known, retail thefts are becoming more frequent and big problem [4]. Thus, for example, in U.S.

they are greater than $1 \%$ of sales (Table 4$)$. This is certainly the case with other countries.

Table 4. Retail theft in the U.S. (in percentage of sales)

\begin{tabular}{|l|l|l|l|}
\hline & 2017 & 2016 & 2015 \\
\hline Average & 1,44 & 1,38 & 1,38 \\
\hline Medium & 1,20 & 1,21 & 1,18 \\
\hline
\end{tabular}

Source: 2017 National Retail Security Survey. Industry Research, NRF - National Retail Federation, Appris Retail, UF - University of Florida, https://nrf.com/system/tdf/Documents/NRSSIndustry-Research-Survey-

2017.pdf?file=1\&title=National\%20Retail\%20Security\%20Survey\%202017(July 12, 2018)

Sources of inventory shrinkage in retail are:customers, presents sources of retail theft in U.S. for the period employees, administrative paperwork mistakes, suppliers and others. For illustration purposes Table 5 2015-2017.

Table 5. Sources of inventory shrinkage in retail in U.S. (average)

\begin{tabular}{|l|l|l|l|}
\hline & 2017 & 2016 & 2015 \\
\hline $\begin{array}{l}\text { Shoplifting / external } \\
\text { (including ORC - } \\
\text { Organized Retail Crime) }\end{array}$ & $36,5 \%$ & $39,3 \%$ & $38,0 \%$ \\
\hline Employee theft / internal & $30,0 \%$ & $35,8 \%$ & $34,5 \%$ \\
\hline $\begin{array}{l}\text { Administrative and } \\
\text { paperwork error }\end{array}$ & $21,3 \%$ & $16,8 \%$ & $16,5 \%$ \\
\hline Vendor fraud or error & $5,4 \%$ & $4,8 \%$ & $6,8 \%$ \\
\hline Unknown loss & $6,8 \%$ & $7,2 \%$ & $6,1 \%$ \\
\hline
\end{tabular}

Source: 2017 National Retail Security Survey. Industry Research, NRF - National Retail Federation, Appris Retail, UF University of Florida, https://nrf.com/system/tdf/Documents/NRSS-Industry-Research-Survey2017.pdf?file=1\&title=National\%20Retail\%20Security\%20Survey\%202017(July 12, 2018)

The data in the given table show that in the U.S., customers and employees participate with the highest rate of stealing in retail trade.

The situation can be "optimized" by preventive action largely by the application of modern information and communication technology, video surveillance, especially radio frequency identification - RFID.

Intangible assets significantly influence the creation of additional value of the product, i.e. the value of the firm. This is shown by the data in Table 6 on the example of German cars for 2014. 
Table 6. Decomposition of value of German "cars", 2014

\begin{tabular}{|l|l|l|l|l|}
\hline & \multicolumn{1}{|c|}{ Distribution } & $\begin{array}{c}\text { Final stage of } \\
\text { production }\end{array}$ & $\begin{array}{l}\text { Other stages of } \\
\text { production }\end{array}$ & Total \\
\hline $\begin{array}{l}\text { Intangible } \\
\text { capital }\end{array}$ & 1,9 & 13,2 & 12,4 & 27,5 \\
\hline Tangible capital & 0,9 & 3,6 & 10,5 & 15,0 \\
\hline Labour & 7,6 & 17,9 & 32,0 & 57,5 \\
\hline Total & 10.4 & 34,7 & 54,9 & 100,0 \\
\hline
\end{tabular}

Source: Chen, (2017)

The data in the given table show that in the creation of additional value labor participate with $57.5 \%$, intangible assets with $27.5 \%$ and tangible assets with $15 \%$ in production of German "cars". In this distribution, it participates with total of $10.4 \%$. For these reasons, considerable attention has recently been given to the most efficient use of intangible assets in all companies, including trading. In other words, because of the increasing importance, investments in intangible assets are increasing. Thus, for example, the ratio of investment in intangible and tangible assets in UK trade in 2015 was 1.37: 1 [16].

There is a significant investment in the use of new information and communication technologies of all kinds in trading business [6]. For illustration purposes, Table 7 shows the use of information and communication technology in the trade of selected countries for 2017.

Table 7. Use of information and communication technologies in the trade of selected countries, 2017

\begin{tabular}{|l|l|l|}
\hline & Retail trade & Wholesale trade \\
\hline France & $76,84 \%$ & $57,22 \%$ \\
\hline Germany & $93,31 \%$ & $78,48 \%$ \\
\hline Italy & - & $52,65 \%$ \\
\hline United Kingdom & $90,05 \%$ & $64,32 \%$ \\
\hline Slovenia & 95,73 & 87,20 \\
\hline Serbia & Wholesale and retail trade 99,7\% \\
\hline
\end{tabular}

The data in the given table show that there is a significant use of new information and communication technology in all observed countries, with the higher rate in wholesale than in retail trade.

The use information and communication technology in wholesale and retail trade in Serbia is also very important. Foreign companies operating in the retail market of Serbia, such as Delhaize Serbia, MercatorS, Metro Group, Lukoil Serbia, OMW Serbia, MOL Serbia and others contribute greatly to this.

The significant use of information and communication technology positively reflects the cost-effectiveness and profitability of modern trade.

\section{DEFINITION OF INTANGIBLE COSTS AND AMORTIZATION OF INTANGIBLE ASSETS IN TRADE COMPANIES}

Intangible costs are priceless in relation to the identified sources. They include different costs such as loss of productivity, customer goodwill, employee morale, loss of brand value, or the collapse of corporate reputation. Given that these costs do not have any concrete value, management estimates them to see their impact on productivity, cost efficiency, and company competitiveness.

They are partly expressed through amortization of intangible assets.

Empirical research found that intangible costs are very important factor in the performance of all companies, including trading.

For these reasons it is necessary to manage them more efficiently with the aim of achieving profit and other goals. Table 8 shows amortization of intangible assets, as part of intangible costs of the selected global retailers. 
Table 8. Amortization of intangible assets of the selected global retailers (in USD million)

\begin{tabular}{|c|c|c|c|c|c|}
\hline & 2013 & 2014 & 2015 & 2016 & 2017 \\
\hline \multicolumn{6}{|l|}{ eBay Inc. } \\
\hline Sales/Revenue & 16.05B & 8.79B & $8.59 \mathrm{~B}$ & 8.98B & $9.6 \mathrm{~B}$ \\
\hline Amortization of intangible assets & 424M & $120 \mathrm{M}$ & $66 \mathrm{M}$ & $56 \mathrm{M}$ & $64 \mathrm{M}$ \\
\hline $\begin{array}{l}\text { Amortization of intangible assets share in } \\
\text { sales, }(\%)^{*}\end{array}$ & 2,64 & 1,36 & 0,76 & 0,62 & 0,66 \\
\hline \multicolumn{6}{|l|}{ Amazon.com.Inc. } \\
\hline Sales/Revenue & $74.45 B$ & 88.99B & 107.01B & 135.99B & 177.87B \\
\hline Amortization of intangible assets & $168 \mathrm{M}$ & $181 \mathrm{M}$ & $270 \mathrm{M}$ & $287 \mathrm{M}$ & $366 \mathrm{M}$ \\
\hline $\begin{array}{l}\text { Amortization of intangible assets share in } \\
\text { sales, }(\%)^{*}\end{array}$ & 0,22 & 0,20 & 0,25 & 0,21 & 0,20 \\
\hline \multicolumn{6}{|l|}{ Sears Holdings Corp. } \\
\hline Sales/Revenue & $36.19 B$ & $31.2 \mathrm{~B}$ & $25.15 B$ & $22.14 \mathrm{~B}$ & 16.7B \\
\hline Amortization of intangible assets & $29 M$ & $18 \mathrm{M}$ & $7 \mathrm{M}$ & $5 \mathrm{M}$ & $4 \mathrm{M}$ \\
\hline $\begin{array}{l}\text { Amortization of intangible assets share in } \\
\text { sales, }(\%)^{*}\end{array}$ & 0,08 & 0,05 & 0,02 & 0,02 & 0,02 \\
\hline \multicolumn{6}{|l|}{ Kroger Co. } \\
\hline Sales/Revenue & 98.38B & 108.47B & 109.83B & 115.34B & 122.66B \\
\hline Amortization of intangible assets & $18 \mathrm{M}$ & $41 \mathrm{M}$ & $51 \mathrm{M}$ & $63 \mathrm{M}$ & $59 \mathrm{M}$ \\
\hline $\begin{array}{l}\text { Amortization of intangible assets share in } \\
\text { sales, }(\%)^{*}\end{array}$ & 0,01 & 0,03 & 0,04 & 0,05 & 0,04 \\
\hline \multicolumn{6}{|l|}{ Target Corp. } \\
\hline Sales/Revenue & $71.28 \mathrm{~B}$ & $72.62 \mathrm{~B}$ & $73.79 B$ & $69.5 B$ & $71.88 \mathrm{~B}$ \\
\hline Amortization of intangible assets & $20 \mathrm{M}$ & $22 \mathrm{M}$ & $23 \mathrm{M}$ & $18 \mathrm{M}$ & $16 \mathrm{M}$ \\
\hline $\begin{array}{l}\text { Amortization of intangible assets share in } \\
\text { sales, }(\%)^{*}\end{array}$ & 0,02 & 0,03 & 0,03 & 0,02 & 0,02 \\
\hline \multicolumn{6}{|l|}{ Tesco PLC } \\
\hline Sales/Revenue & $63.65 B$ & $56.93 B$ & 53.93B & $55.92 B$ & $57.49 \mathrm{~B}$ \\
\hline Amortization of intangible assets & $227 \mathrm{M}$ & $248 M$ & $246 M$ & $244 \mathrm{M}$ & $219 M$ \\
\hline Amortization of int. ass..share in sales, $\%^{*}$ & 0,35 & 0,43 & 0,45 & 0,43 & 0,38 \\
\hline
\end{tabular}

Note: * Calculations performed by the author Source: https://www.marketwatch.com (July 12, 2018)

Thus, for example, they are very significant with the retail company eBay Inc. and Tesco PLC than other surveyed retailers. For the purpose of more complete comparative analysis, Table 9 shows the amortization of intangible assets in the trade of Russia. 
Table 9. Amortization of intangible assets in trade of Russia, 2010 - 2016, (in percentage of total expenditures)

\begin{tabular}{|l|l|l|l|l|}
\hline & 2010 & 2014 & 2015 & 2016 \\
\hline Motor vehicles and repair trade & 0,0 & 0,1 & 0,1 & 0,1 \\
\hline $\begin{array}{l}\text { Wholesale trade, motor vehicles and } \\
\text { repair trade excluded }\end{array}$ & 0,2 & 0,1 & 0,1 & 0,2 \\
\hline $\begin{array}{l}\text { Retail trade, motor vehicles and } \\
\text { repair trade excluded }\end{array}$ & 0,1 & 0,5 & 0,2 & 0,3 \\
\hline Social nutrition & 0,0 & 0,4 & 0,2 & 0,0 \\
\hline
\end{tabular}

Source: Российский статистический ежегодник. 2017:Стат.сб./Росстат. -Р76 М., 2017 -686с.

The data in the given table show that the amortization of intangible assets in Russia is higher in retail trade than in wholesale trade, which by itself shows that the investments in intangible assets in retail trade are higher to that of wholesale.

\section{INTANGIBLE COSTS OF TRADING COMPANIES IN SERBIA}

Starting from the above presented general definition and significance of intangible costs, as well as their analysis with global retailers, in further discussion of the treated issues, we will look in detail on the factors of the trend of intangible costs of trade enterprises in Serbia. Table 10 shows intangible costs in various economy sectors in Serbia for 2016 and 2017.

Table 10. Intangible costs of some economy sectors in Serbia, 2016 and 2017, (\% of total revenues)

\begin{tabular}{|l|l|l|}
\hline & 2017 & 2016 \\
\hline Economy & 4,38 & 4,39 \\
\hline Agriculture, forestry and fishery & 3,23 & 2,93 \\
\hline Mining & 5,73 & 6,21 \\
\hline Processing industry & 3,14 & 3,27 \\
\hline Electrical energy supply & 5,19 & 5,77 \\
\hline Water supply & 5,19 & 5,19 \\
\hline Construction & 5,02 & 5,35 \\
\hline Wholesale and retail trade... & 2,51 & 2,43 \\
\hline Transportation and accommodation & 5,65 & 5,95 \\
\hline Accommodation and nutrition service & 20,28 & 16,58 \\
\hline Information and communication & 9,46 & 7,98 \\
\hline Financial and insurance business & 3,68 & 4,00 \\
\hline Real estate business & 10,20 & 11,25 \\
\hline Professional and scientific activities & 10,18 & 9,58 \\
\hline Administrative and auxiliary service activities & 9,51 & 9,66 \\
\hline State administration and defence & 9,07 & 10,23 \\
\hline Education & 10,29 & 11,09 \\
\hline Health and social protection & 3,08 & 4,52 \\
\hline Art, entertainment and recreation & 34,93 & 49,78 \\
\hline Other service activities & 8,08 & 8,64 \\
\hline Household activities & - & - \\
\hline Exterritorial organization activities & - & - \\
\hline Descriptive Statistics & & \\
\hline Mean & 8,6537 & 9,4953 \\
\hline Std. Error of Mean & 1,74637 & 2,38291 \\
\hline Median & 5,7300 & 6,2100 \\
\hline Std. Deviation & 7,61225 & 10,38685 \\
\hline Minimum & 2,51 & 2,43 \\
\hline Maximum & 34,93 & 49,78 \\
\hline
\end{tabular}

Note: Calculations performed by the author. Descriptive statistics are calculated using the statistical software program SPSS Source: Business Registers Agency

The data in the table show that intangible costs participated in total trade revenues in Serbia in 2016 
with 2, 43\% and in 2017 with $2.51 \%$. Compared to the total economy of Serbia and certain sectors (especially: Accommodation and food services sectors), they are lower in trade.

Observed by individual countries, especially compared to comparable countries of developed market economies, intangible costs in Serbian trade are also lower. In other words, this means lower investment in intangible assets, as a factor in the performance of trading companies in Serbia. The share of intangible assets of trade in total intangible assets of the Serbian economy in 2017 was $12.3 \%$ (Calculation performed by the author according to the data of the Business Registers Agency). It is certainly lower than the trade of developed economies. For comparison, the share of intangible trade assets in total intangible assets in 2015 amounted to $13.8 \%$ in the UK (Martin, 2018). Nevertheless, intangible assets are significant in Serbian trade. Due to its importance, it is necessary that trade companies in Serbia invest as much as possible in intangible assets.

This will positively affect the creation of additional value as well as their overall performance. As the determinant of intangible costs, Table 11 shows the size of the intangible assets of trade companies in Serbia for the period $2013-2017$.

Table 11. Intangible assets of trade companies in Serbia, $2013-2017$

\begin{tabular}{|l|l|l|l|l|l|l|}
\hline & \multicolumn{1}{|c|}{$\begin{array}{c}\text { Assets (million } \\
\text { dinars) }\end{array}$} & $\begin{array}{c}\text { Tangible } \\
\text { assets (million } \\
\text { dinars) }\end{array}$ & $\begin{array}{c}\text { Intangible } \\
\text { assets(million } \\
\text { dinars) }\end{array}$ & $\begin{array}{c}\text { Share of } \\
\text { intangible } \\
\text { assets in } \\
\text { total } \\
\text { assets, } \\
\%^{*}\end{array}$ & $\begin{array}{c}\text { Intangible } \\
\text { assets/ } \\
\text { Tangible } \\
\text { assets } \\
\text { ratio* }\end{array}$ & $\begin{array}{c}\text { Return } \\
\text { on } \\
\text { assets }\end{array}$ \\
\hline 2013 & 2.160 .474 & 2.122 .780 & 37.694 & 1,74 & 0,02 & 4,15 \\
\hline 2014 & 2.077 .002 & 2.048 .985 & 28.017 & 1,35 & 0,01 & 4,03 \\
\hline 2015 & 2.234 .368 & 2.199 .218 & 35.150 & 1,57 & 0,02 & 4,33 \\
\hline 2016 & 2.311 .644 & 2.275 .377 & 36.107 & 1,56 & 0,02 & 4,52 \\
\hline 2017 & 2.393 .721 & 2.357 .525 & 36.196 & 1,51 & 0,02 & 5,29 \\
\hline $\begin{array}{l}\text { Descriptive } \\
\text { Statistics }\end{array}$ & & & & & & \\
\hline Minimum & $2.077 .002,00$ & $2.048 .985,00$ & $28.017,00$ & $1.35,00$ & $0.01,00$ & $4.03,00$ \\
\hline Maximum & $2.393 .721,00$ & $2.357 .525,00$ & $37.694,00$ & $1.74,00$ & $0.02,00$ & $5.29,00$ \\
\hline Mean & $2.235 .441,8000$ & $2.200 .777,000$ & $34.632,800$ & $1.54,6000$ & $0.01,8000$ & $4.46,400$ \\
\hline $\begin{array}{l}\text { Std. } \\
\text { Deviation }\end{array}$ & 124080,19055 & 121718,80428 & 3808,67795 & 13,97498 &, 44721 & 49,75741 \\
\hline Median & 2234368,0000 & 2199218,0000 & 36107,0000 & 1,5600 &, 0200 & 4,3300 \\
\hline CAGR & $2,07 \%$ & $2,12 \%$ & $-0,81 \%$ & $-2,80 \%$ & $0,00 \%$ & $4,97 \%$ \\
\hline
\end{tabular}

Note: *Calculations performed by the author. Descriptive statistics are calculated using the statistical software program SPSS, Source: Business Registers Agency

In the observed period (2013 - 2017), the trade of Serbia on average was: assets 2,235,441 million dinars, tangible assets $2,200,777$ million dinars, intangible assets 34,632 million dinars, share of intangible assets in total assets $1,54 \%$, intangible assets / tangible assets ratio is 0.01 and return on assets is $4.46 \%$. The average median ratio is: share of intangible assets in total assets 1,5600 (1.56\%) and return on assets $4,3300(4.33 \%)$.

The return on investment measured by the compound annual growth rate (CAGR - Compound Annual Growth Rate) in Serbia's trade for a five-year period amounted to: assets $2.07 \%$, tangible assets
$2.12 \%$, and intangible assets $-0.81 \%$. The annual growth rate for a five-year period is: share of intangible assets in total assets $-2.80 \%$, intangible assets / tangible assets ratio $0.00 \%$ and return on assets $4.97 \%$.

Intangible assets / tangible assets ratio in Serbian trade is significantly lower than in developed economies (US, EU, UK). In addition, in the observed five-year period (2013 - 2017, N 5), there was a (negative) weak correlation between the share of intangible assets in total assets and return on assets (Pearson Correlation, 029, Sig. (1-tailed), 482, (Table 12). This itself points to the fact that the trading 
companies in Serbia should invest more in intangible assets in the future.

Table 12. Correlation analysis

Correlations

\begin{tabular}{|c|c|c|c|}
\hline & & Return on assets & $\begin{array}{l}\text { Share of intangible } \\
\text { assets in total assets }\end{array}$ \\
\hline \multirow{3}{*}{ Pearson Correlation } & Return on assets & 1,000 &,- 029 \\
\hline & $\begin{array}{l}\text { Share of intangible } \\
\text { assets in total assets }\end{array}$ &,- 029 & 1,000 \\
\hline & Return on assets & & ,482 \\
\hline \multirow[t]{2}{*}{ Sig. (1-tailed) } & $\begin{array}{l}\text { Share of intangible } \\
\text { assets in total assets }\end{array}$ &, 482 & \\
\hline & Return on assets & 5 & 5 \\
\hline $\mathrm{N}$ & $\begin{array}{l}\text { Share of intangible } \\
\text { assets in total assets }\end{array}$ & 5 & 5 \\
\hline
\end{tabular}

Note: Calculations performed by the author. Descriptive statistics are calculated using the statistical software program SPSS

Table 13 shows the results of regression analysis intangible assets in total assets - independent (return on assets - dependent variable and share of variable).

Table 13. Regression analysis

\section{Model Summary}

\begin{tabular}{|c|c|c|c|c|c|c|c|c|c|c|}
\hline \multirow{2}{*}{$\begin{array}{l}\text { Mo } \\
\text { del }\end{array}$} & \multirow[t]{2}{*}{$\mathrm{R}$} & \multirow{2}{*}{$\begin{array}{c}\text { R } \\
\text { Squar } \\
\text { e }\end{array}$} & \multirow{2}{*}{$\begin{array}{c}\text { Adjusted } \\
\text { R } \\
\text { Square }\end{array}$} & \multirow{2}{*}{$\begin{array}{c}\text { Std. } \\
\text { Error of } \\
\text { the } \\
\text { Estimate }\end{array}$} & \multicolumn{5}{|c|}{ Change Statistics } & \multirow{2}{*}{$\begin{array}{l}\text { Durbin- } \\
\text { Watson }\end{array}$} \\
\hline & & & & & $\begin{array}{c}\mathrm{R} \\
\text { Square } \\
\text { Change }\end{array}$ & $\begin{array}{c}F \\
\text { Chan } \\
\text { ge }\end{array}$ & $d f 1$ & df2 & $\begin{array}{c}\text { Sig. F } \\
\text { Change }\end{array}$ & \\
\hline 1 & ,029a & ,001 &,- 332 & ,57431 & ,001 & ,002 & 1 & 3 & ,963 & ,758 \\
\hline
\end{tabular}

a. Predictors: (Constant), Share of intangible assets in total assets

b. Dependent Variable: Return on assets

\section{ANOVA $^{a}$}

\begin{tabular}{|rl|r|r|r|r|r|}
\hline Model & Sum of Squares & df & Mean Square & F & Sig. \\
\hline \multirow{2}{*}{1} & Regression &, 001 & 1 &, 001 &, 002 &, $963^{\mathrm{b}}$ \\
& Residual &, 989 & 3 &, 330 & & \\
& Total &, 990 & 4 & & & \\
\hline
\end{tabular}

a. Dependent Variable: Return on assets b. Predictors: (Constant), Share of intangible assets in total assets

\section{Coefficients $^{\mathrm{a}}$}

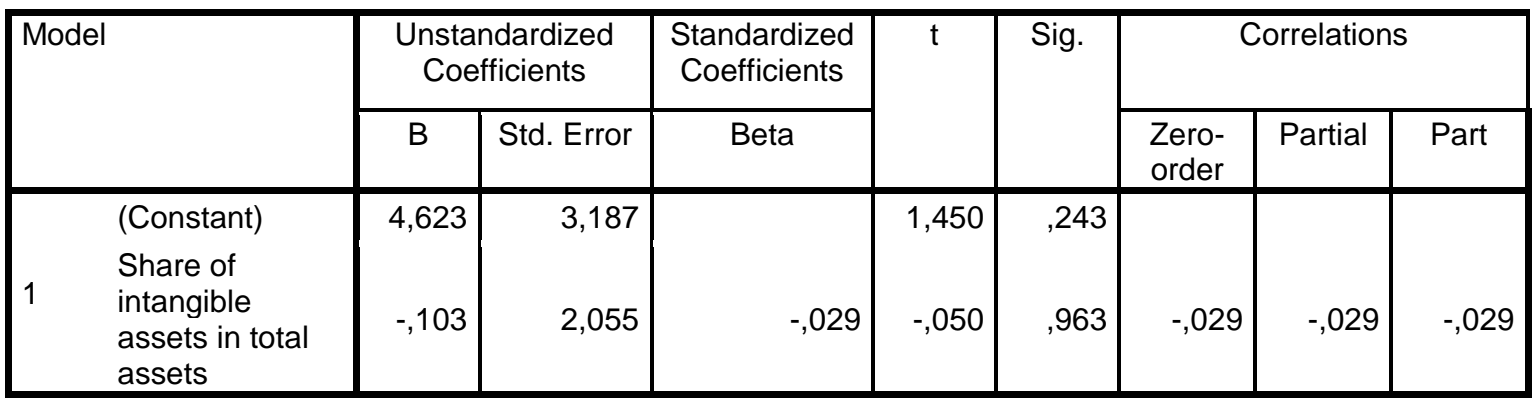

a. Dependent Variable: Return on assets Note: Calculations performed by the author. Descriptive statistics are calculated using the statistical software program SPSS 
The determination coefficient is: Adjusted R Square -, 332. Therefore, the correlation between the respective sizes is weak.

\section{Linear regression is:}

$\mathrm{Y}=\mathrm{a}+\mathrm{bX}$

i.e.

$Y=4.623-, 1013 X$,

where: $Y=$ return on assets, $X=$ share of intangible assets in total assets.

On the basis of the obtained results of the statistical analysis, it can be concluded that there is a poor correlation between the intangible assets and returns on assets of trade companies in Serbia. In order to improve the performance of trade companies in Serbia it is necessary to invest much more in intangible assets in the future. This is particularly true for domestic chains. Intangible costs of trading companies in Serbia are becoming more significant (Table 14, and Figure 1). They participate in total revenues with approximately $2.50 \%$. In the three-year period, intangible costs increased from 77,152 to 89.586 million dinars. The return on investments (expressed in intangible costs), measured by the compound annual growth rate (CAGR - Compound Annual Growth Rate), which provides a clearer picture of the annual return on investment, was $5.04 \%$. The annual rate of increase in the share of intangible costs in total revenues is $0.13 \%$.

Table 14. Intangible costs of trade companies in Serbia, $2015-2017$

\begin{tabular}{|l|l|l|}
\hline & \multicolumn{1}{|c|}{ dinars) } & $\begin{array}{c}\text { Intangible costs (million } \\
\text { in total revenue, \%* }\end{array}$ \\
\hline 2015 & 77.152 & 2,50 \\
\hline 2016 & 82.586 & 2,43 \\
\hline 2017 & 89.413 & 2,51 \\
\hline Descriptive Statistics & & \\
\hline Mean & 83050,3333 & 2,4800 \\
\hline Std. Error of Mean & 3547,05203 &, 02517 \\
\hline Median & 82586,0000 & 2,5000 \\
\hline CAGR - Compound Annual Growth Rate & $5,04 \%$ & $0.13 \%$ \\
\hline
\end{tabular}

Note: Calculations performed by the author. Descriptive statistics are calculated using the statistical software program SPSS, Source: Business Registers Agency

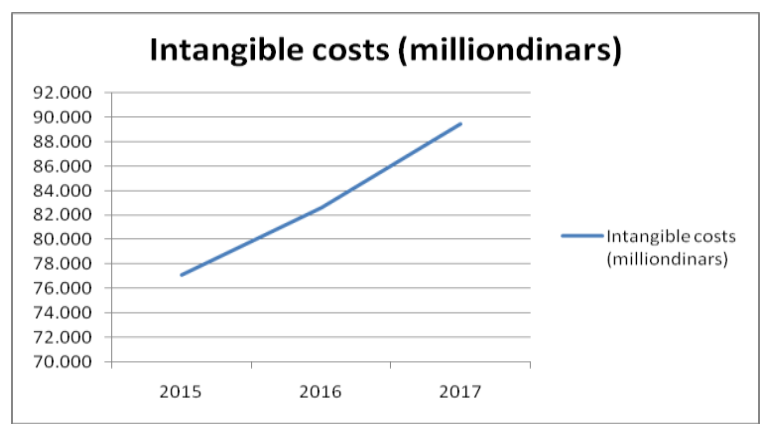

Figure 1. The dynamics of intangible costs of trade in Serbia Note: The author's picture
Entrepreneurs in Serbia have an important role in creating added value in trading business. In view of

this, it is necessary to look at their intangible costs in order to thoroughly analyze the problems discussed in this paper. The share of intangible costs in total income of entrepreneurs in Serbia is about $2 \%$ (Table 15). In order to improve overall performance in the future, it is therefore necessary that entrepreneurs in Serbia trade significantly invest in intangible assets.

Table 15. Intangible costs of entrepreneurial trade in Serbia, 2016 and 2017

\begin{tabular}{|l|l|l|l|}
\hline & 2017 & 2017 & Index 2017/2016 \\
\hline Revenues (million dinars) & 115.269 & 113.634 & 101.4 \\
\hline Intangible costs (million dinars) & 2.359 & 2.303 & 102.4 \\
\hline $\begin{array}{l}\text { Share of intangible costs in total } \\
\text { revenue, \%* }\end{array}$ & 2.05 & 2.03 & 100.9 \\
\hline
\end{tabular}

Note: Calculations performed by the author Source: Business Registers Agency

Table 16 presents selected retail chains in Serbia for

2016 and data on intangible costs of trade. 
Table 16. Intangible costs of selected retailers in Serbia, 2016.

\begin{tabular}{|l|l|l|l|}
\hline & \multicolumn{1}{|c|}{$\begin{array}{c}\text { Revenues (million } \\
\text { dinars) }\end{array}$} & \multicolumn{1}{|c|}{$\begin{array}{c}\text { Intangible costs } \\
\text { (million dinars) }\end{array}$} & $\begin{array}{c}\text { Share of intangible costs } \\
\text { in total revenue, } \% *\end{array}$ \\
\hline Mercator-S & 107.136 & 1.483 & 1,38 \\
\hline Delhaize Serbia & 85.025 & 1.962 & 2,31 \\
\hline Knelt Co. & 75.809 & 531 & 0,70 \\
\hline Metro Cash\&Carry DOO Beograd & 26.109 & 1.294 & 4,95 \\
\hline C Market & 26.746 & 744 & 2,78 \\
\hline IDEA & 2.948 & 150 & 5,09 \\
\hline FOENIX PHARMA & 34.451 & 279 & 0,81 \\
\hline VELETABAK & 30.257 & 476 & 1,57 \\
\hline DIS Trgovina & 23.295 & 226 & 0,97 \\
\hline Knez Petrol & 36.587 & 138 & 0,38 \\
\hline LukoilSrbija & 29.087 & 590 & 2,03 \\
\hline OMV Srbija & 28.132 & 525 & 1,86 \\
\hline MOL Srbija & 25.497 & 344 & 1,35 \\
\hline NIS & 192.104 & 13.282 & 6,91 \\
\hline Descriptive Statistics & & \\
\hline Median & 29672,0000 & 528,0000 & 1,7150 \\
\hline
\end{tabular}

Note: Calculations performed by the author. Descriptive statistics are calculated using the statistical software program SPSS, Source: Business Registers Agency

The data in Table 17 and Figure 2 show that the efficiency of the intangible cost management in Serbian trading companies was very unsatisfactory in 2016. In view of this, it is necessary to take appropriate measures in the future in order to increase the

efficiency of intangible assets management of, i.e. intangible costs, which will certainly have a positive effect on their overall performance. In addition to this, the fact is that there is a strong correlation between intangible costs and sales revenues.

Table 17. Efficiency of intangible cost management of trading companies in Serbia

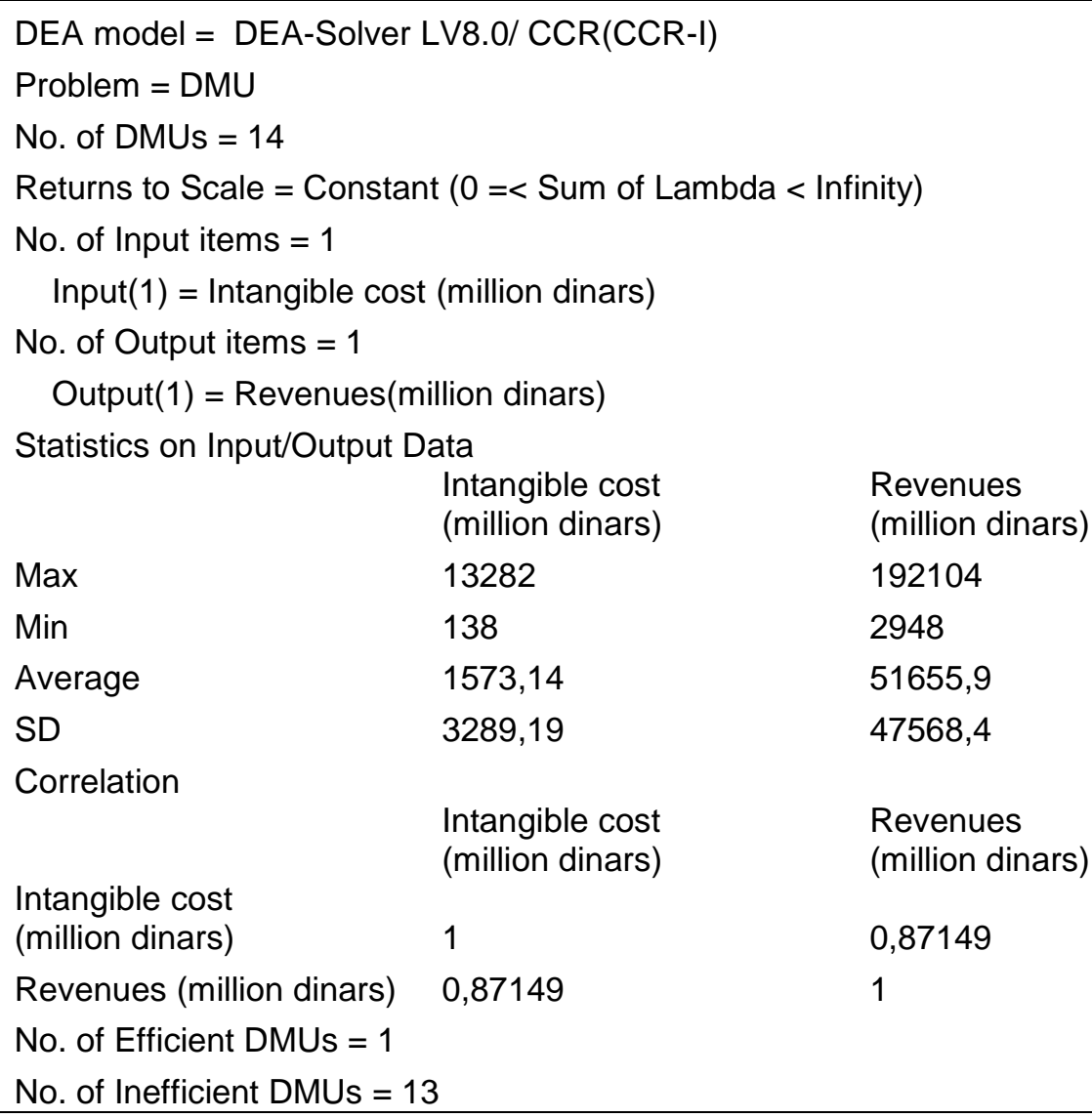




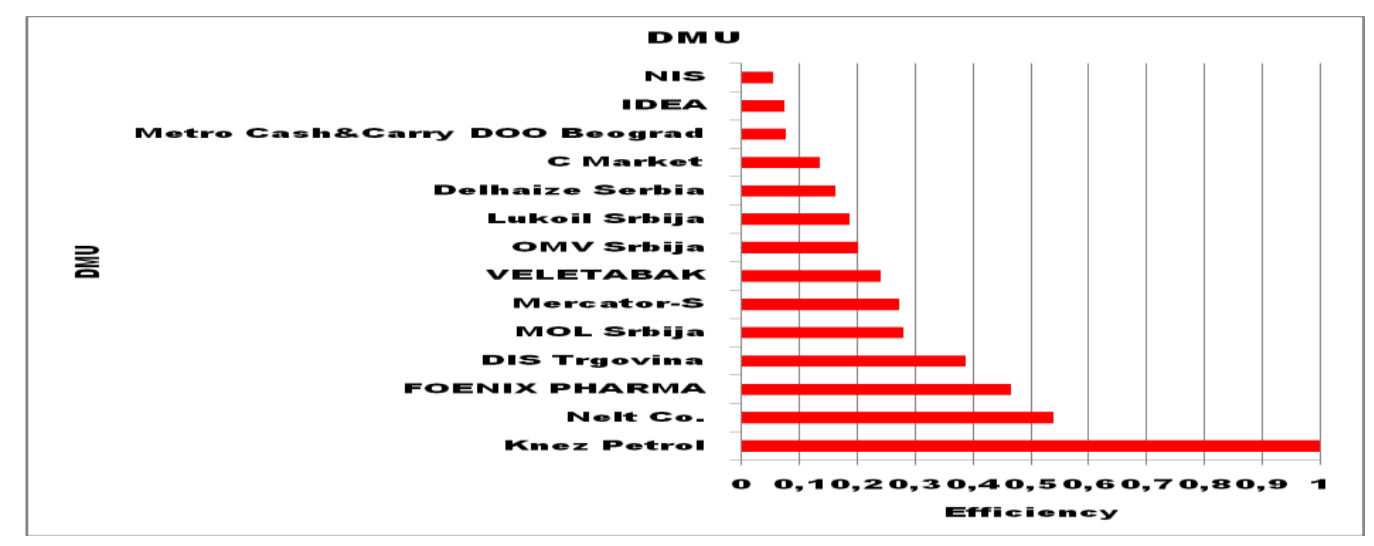

Figure 2. Efficiency of trade companies in Serbia Note: The author's picture

The data in the given table show that there is a difference in the participation of intangible costs in total revenues in some observed retail chains in Serbia. It ranged from $0.38 \%$ in 2016 (Knez Petrol) to 6.91\% (NIS). On average (median) it was $1.71 \%$. Foreign retail chains have greater participation of intangible costs than domestic ones. This suggests that they should invest significantly more in intangible assets as a key performance factor. In order to obtain the best possible representation of the intangible costs of trading companies in Serbia, Table 18 shows the percentage share of cash expenditures for certain intangible assets (concessions, patents, licenses, trade and service marks, software and other rights) in the revenues of Delhaize Serbia for the period 2015 - 2017, which is very significant for participation in the sale in the retail market in Serbia.

Table. 18. Participation of monetary expenditures for the concession, patents, licenses, trade and service marks, software and other rights in the revenues of Delhaize Serbia, $2015-2017$

\begin{tabular}{|l|l|l|l|}
\hline $\begin{array}{l}\text { Participation of monetary expenditures for the concession, patents, } \\
\text { licenses, trade and service marks, software and other rights in the } \\
\text { revenues, (\%) }\end{array}$ & 0,23 & 0,68 & 0,58 \\
\hline Share of intangible assets in total assets, (\%) & 6,36 & 6,25 & 7,34 \\
\hline Intangible assets / tangible assets ratio & 0,07 & 0,07 & 0,08 \\
\hline
\end{tabular}

Note: Calculations performed by the author, Source: Business Registers Agency

The data in the given table show that the domestic retail companies increased their investments in intangible assets recently. This had a favorable effect on its overall performance. Nevertheless, they are still less than other comparable global retailers. All this points to the fact that is necessary to invest more in intangible assets in order to increase the profits of commercial companies in Serbia in the future.

\section{CONCLUSION}

Lately, due to its increasing importance, both in theory and in practice, the influence of intangible assets, i.e. intangible costs on the performance of trading enterprises, is being investigated. The size of the intangible costs of trade enterprises varies by country. Thus, for example, amortization of intangible assets of trade is lower in Russia than in the USA. As well as in Russia, the situation is similar with the trade in Serbia. As far as trade companies in Serbia are concerned, share of intangible costs in total costs, i.e. revenues constantly increases. They are becoming important factor in the performance of trade companies in Serbia. There is a strong correlation between the intangible costs and revenues from the sale of trade companies in Serbia. In view of this, it is necessary to manage the intangible assets more intensively, that is, the intangible costs of trading companies in Serbia in the future in order to achieve profit goals, with the maximum satisfaction of the consumers' needs.

\section{REFERENCES}

[1] Beck, A. (2018),Measuring the impact of RFID in retailing: Keys Lessons from 10 Case-study Companies, University of Leicester.

[2] Berman.B. and Evans. J. R. (2013), Retail Management, Boston: Prentice Hall.

[3] Chen, W., gouma, R., Los, B. and Timmer, M.P. (November 2017), Measuring the income to intangibles in goods production: a global value chain approach. Economic Research Working Paper No. 36, WIPO- World Intellectual Property Organization, pp.1-73.

[4] Chioma Vivian Amasiatu, Mahmood Hussain Shah, (2018), First party fraud management: framework for the retail industry, International Journal of Retail \& Distribution Management, 46(4),pp.350-363. 
[5] Corrado, C., Haskel, J., Jona-Lasinio, C. and Iommi, M. (2018), Intangible investment in the EU and US before and since the Great Recession and its contribution to productivity growth, Journal of infrastructure, Policy and Development, 2(1), pp.1136.

[6] Dhruv Grewal, Scott Motyka, and Michael Levy (2018), The Evolution and Future of Retailing and Retailing Education, Journal of Marketing Education, 40(1), pp.85 -93.

[7] Ivanov, G. and Mayorova, E. (2015), Intangible Assets and Competitive Advantage in Retail: Case Study from Russia, Asian Social Science, 11(12),pp. 38-45.

[8] Jasek, P, Vrana, L., Sperkova, L., Smutny, Z. and Kobulsky, M. (2018), Modeling and Application of Customer Lifetime Value in Online Retail, Informatics, 5(2), pp. 1-22.

[9] Kim, D., Jung, G.O., and Par, H.H. (2015), Manufacturer's retailer dependence: A private branding perspective, Industria Marketing Management, 49, 95-104.

[10] Levy, M. Weitz. B. A. and Grewal. D. (2014), Retailing Management, New York: McGraw-Hill.

[11] Lukic, R. (2011), The Effect of Private Brands on Business Performance in Retail, Economia. Seria Management, 14(1), pp. 25-39.

[12] Lukić, R. (2011), Evoluacija poslovnih performansi u maloprodaji, Beograd: Ekonomski fakultet

[13] Lukic, R., Lalic, S. and Vojteski-Kljenak, D. (2016), Research and Development Costs in Retail Trade, Management and Economic Review, 1(2), pp.170-182.

[14] Lukic, R. and Vojteski-Kljenak, D. (2017), A nalysis of Intangible Assets in Retail Trade, Strategic Management, 22(2), pp. 18-26.
[15] Lukić, R. (2018), Računovodstvo trgovinskih preduzeća, Beograd: Ekonomski fakultet.

[16] Martin, J. (2018), Experimental estimates of investment in intangible assets in the UK:2015, Office for National Statistics, pp. 1-20.

[17] Perović, V., (2016) Uloga i značaj primene kontrolinga u poslovnoj praksi, Računovodstvo, Časopis za računovodstvo, reviziju i poslovne finansije, God. LX, Br. 1-2016, str. 168 - 183, ISSN: 1450-6114

[18] Perović V., Vujičić M., (2015) Controlling: between theory and practice, International Journal of Industrial Engineering and Management - IJIEM, Vol. 6, No 4-2015, pp. 165-170, ISSN: 2217-2661 http://ijiemjournal.uns.ac.rs

[19] Perovic, V., Kontroling, (2007), Rodacomm, Novi Sad, ISBN: 978-86-7473-329-5

[20] Sinanaj, G. (2017), Intangible Costs of Data Breach Events, Dissertation, Fakultä der Georg-August-Universität Göttingen, pp.1-119.

[21] Todorovic-Dudic, A, Stanisic, M, Perovic, V, (2017) ,Contribution of controlling to business efficiency, Industrija, vol. 45, br. 1, pp. 25-44 doi:10.5937/industrija45-11003 ISSN: 2334-8526

[22] Thum-Thysen, A., Voigt, P., Bilbao-Osorio, B., Maier, C. and Ognyanova, D. (May 2017), Unlocking Investment in Intangible Assets.Discussion Paper 047, European Commission, pp.1-52.

[23] (2017) National Retail Security Survey, Industry Research, NRF - National Retail Federation, Appris Retail, UF - University of Florida, pp. 1-20.

\title{
Analiza nematerijalnih troškova trgovinskih kompanija u srbiji
}

\author{
Radojko Lukić, Veselin Perović
}

Primljen (28.12.2018.); Recenziran (11.01.2019.); Prihvaćen (20.02.2019.)

\begin{abstract}
Abstrakt
U poslednje vreme se u teoriji i praksi sve više pažnje posvećuje istraživanju uticaja nematerijalnih sredstava na poslovanje kompanije. U ovom kontekstu, takođe se razmatra značaj nematerijalnih troškova, tj. amortizacije nematerijalnih sredstava. Imajući to u vidu, ovaj rad razmatra uticaj nematerijalnih troškova na poslovanje trgovačkih društava u Srbiji. Zaključak je da su oni sve važniji faktor u poslovanju trgovinskih kompanija u Srbiji. U prilog tome, činjenica je da postoji velika korelacija između nematerijalnih troškova i prihoda od prodaje.
\end{abstract}

Ključne reči: inovacije, kupci, brend, tehnologija, znanje 